\title{
PENGARUH SENAM NIFAS DAN PIJAT OKSITOSIN TERHADAP INVOLUSI UTERI PADA IBU POSTPARTUM
}

\author{
*Inge Anggi Anggarini, Ria Gustirini \\ Program Studi DIII Kebidanan STIKes Muhammadiyah Palembang, ${ }^{*}$ email: anggiinge@gmail.com
}

INFO ARTIKEL
Riwayat Artikel:
Diterima: 13-1 1-2019
Disetujui: 18-03-2020

Kata Kunci:

TFU

Senam Nifas

Pijat Oksitosin

Postpartum

\section{A. LATAR BELAKANG}

Salah satu indikator untuk menentukan derajat kesehatan suatu bangsa ditandai dengan tinggi rendahnya angka kematian ibu. Hal ini merupakan suatu fenomena yang mempunyai pengaruh besar terhadap keberhasilan pembangunan kesehatan. Masa Nifas merupakan hal penting untuk diperhatikan guna menurunkan angka kematian ibu. Setelah persalinan tubuh seorang ibu memasuki masa pemulihan, salah satunya adalah

\begin{abstract}
Abstrak: Salah satu indikator untuk menentukan derajat kesehatan suatu bangsa ditandai dengan tinggi rendahnya angka kematian ibu. Hal ini merupakan suatu fenomena yang mempunyai pengaruh besar terhadap keberhasilan pembangunan kesehatan. Masa Nifas merupakan hal penting untuk diperhatikan guna menurunkan angka kematian ibu. Setelah persalinan tubuh seorang ibu memasuki masa pemulihan, salah satunya adalah involusi uteri yang dimulai segera setelah persalinan dan proses ini harus tuntas setelah 6 minggu.. Ada beberapa upaya yang dapat dilakukan untuk mempercepat proses involus uteri antara lain senam nifas dan pijat oksitosin. Tujuan Penelitian: menganalisis pengaruh kombinasi dari senam nifas dan pijat oksitosin terhadap involusi uteri pada ibu postpartum. Metode Penelitian: Penelitian ini merupakan penelitian quasi eksperimen dengan post test-only control group design. Pengambilan sampel dilakukan secara consecutive sampling. Hasil: Hasil penelitian menunjukkan terdapat perbedaan rerata yang bermakna pada penurunan tinggi fundus uteri antara kelompok perlakuan dan kelompok kontrol $(p<0,05)$. Simpulan:Hasil penelitian ini diharapkan memberikan kontribusi positif terhadap ilmu kebidanan sebagai salah satu upaya nonfarmakologik untuk mempercepat proses involusi uteri sehingga dapat mengurangi perdarahan pada ibu postpartum yang sering terjadi pada masa postpartum karena proses involusi yang tidak berjalan normal (sub involusi uteri) dan dapat mendukung upaya pemerintah dalam mengurangi angka mortalitas dan morbiditas ibu.
\end{abstract}

\begin{abstract}
An indicator to determine the degree of health, high and low maternal mortality rates characterize a nation. It is a phenomenon that has great importance to the increasing success of health development. The puerperium is a crucial thing to consider to reduce maternal mortality. After delivery, the mother's body begins the recovery period, one of which is uterine involution which starts immediately after delivery, and this process completed after six weeks. Read more about the process of returning the uterus to the state before pregnancy after giving birth. This process is critical because puerperal bleeding can occur sooner or later. Several efforts can make to improve the process of uterine involves, including puerperal exercises and oxytocin massage. The aims: to analyze the effect the combination of puerperal exercises and oxytocin massage on uterine involution in postpartum mothers The Method: This research is a quasi-experimental study with post-test only control group design. Sampling has taken as consecutive sampling. The Results: The results showed that there were significant mean differences in the decrease in the height of the fundus between the treatment group and the control group $(p<0.05)$. The conclusion: The results of this study expected to make a positive contribution to midwifery as one of the non-pharmacological efforts to accelerate the process of uterine involution to reduce bleeding in postpartum mothers that often occurs during the postpartum because of involution processes that are not running normally (sub involution uteri) and can support government efforts in reducing maternal mortality and morbidity.
\end{abstract}

involusi uteri yang dimulai segera setelah persalinan dan proses ini harus tuntas setelah 6 minggu. Involusi Uteri adalah suatu proses kembalinya uterus pada keadaan sebelum hamil setelah melahirkan. Proses ini merupakan proses yang sangat penting karena kemungkinan dapat terjadi pendarahan nifas cepat atau lambat ${ }^{1}$

Upaya pencegahan perdarahan post partum dapat dilakukan semenjak persalinan kala 3 dan 4 dengan pemberian oksitosin. Hormon oksitosin ini 
sangat berperan dalam proses involusi uterus. Proses involusi akan berjalan dengan bagus jika kontraksi uterus kuat sehingga harus dilakukan tindakan untuk memperbaiki kontraksi uterus. Hormon oksitosin berguna untuk memperkuat dan mengatur kontraksi uterus, mengompresi pembuluh darah dan membantu hemostasis ibu sehingga mengurangi kejadian atonia uterus terutama pada persalinan lama. Kontraksi uterus yang kuat akan mengakibatkan proses involusi menjadi lebih bagus2

Oksitosin dapat diperoleh dengan berbagai cara baik melalui oral, intranasal, intra-muscular, maupun dengan pemijatan yang merangsang keluarnya hormon oksitosin. Sebagaimana yang ditulis Mark, Rapaport, Schettler, et al., (2012) dalam The Journal of Alternative And Complementary Medicine, bahwa dari data penelitian menunjukkan bahwa terapi pijat memiliki efek secara biologis, jika dilakukan 2 kali dalam 1 minggu dengan sentuhan ringan mempunyai efek perubahan pada neuroendokrin yang dapat memicu pelepasan oksitosin dan dapat menjaga kesetabilan oksitosin.Oksitosin juga disintesis oleh neuron parvoselular dari paraventricular nucleus dari berbagai arah pusat sistem saraf termasuk saraf tulang belakang. Pada tulang belakang terdapat saluran yang dapat mengeluarkan oxytocinergic yang bertugas mengikat hormon oksitosin, pada lapisan permukaan dorsal horn daerah otonom (intermediolateral columns, intermediomedial grey matter, lamina $X$ dan sacral parasimpathetic nucleus) ${ }^{3}$

Senam nifas merupakan suatu latihan yang sederhana di rumah sakit, dan dapat dilanjutkan di rumah yang bertujuan menolong dalam meningkatkan tonus otot, mengurangi berat badan pada masa nifas, dan membantu mencegah konstipasi 4. Senam nifas juga berfungsi untuk menguatkan otot dasar panggul dan juga dapat membantu mengurangi depresi ${ }^{5}$. Senam nifas sebagai salah satu bentuk latihan fisik, akan memberi dampak terhadap sistem kardiovaskuler, aliran darah otot dan curah jantung meningkat begitu pula pada sistim pernafasan dan sistem metabolik dalam perubahan ATP dan ADP dengan pelepasan energi ke otot untuk ber-kontraksi ${ }^{6}$

American College of Obstetrics and Gynecologists (ACOG) merekomendasikan bahwa ibu postpartum yang tidak memiliki komplikasi medis dan obstetrik untuk dapat mengikuti senam nifas mulai dari aktivitas fisik yang sedang sampai aktivitas fisik yang kuat bisa dilakukan dalam beberapa hari dalam seminggu7.

\section{B. METODE PENELITIAN}

Penelitian ini merupakan penelitian quasi eksperimen. Quasi eksperimen dengan rancangan post test-only control group design. Pada desain ini responden penelitian dibagi menjadi dua kelompok, satu kelompok adalah kelompok perlakuan sedangkan kelompok yang satunya adalah kelompok kontrol sebagai pembanding. Kelompok perlakuan diberikan intervensi senam nifas dan pijat oksitosin dalam 24 jam pertama postpartum, sedangkan pada kelompok kontrol tidak diberikan intervensi senam nifas dan pijat oksitosin, tetapi hanya diberikan perawatan standar masa nifas sesuai dengan prosedur tetap (protap) PMB Husniyati dan PMB Misni Herawati.

Cara pengambilan sampel pada penelitian ini menggunakan nonprobability sampling dengan consecutive sampling. Consecutive sampling adalah suatu metode pemilihan sampel yang dilakukan dengan memilih semua individu yang ditemui dan memenuhi kriteria pemilihan, sampai jumlah sampel yang diinginkan oleh peneliti terpenuhi ${ }^{8}$

Penentuan besar sampel dalam penelitian ini menggunakan power and sample size program versi 3.1.2 untuk rumus beda mean dengan keterangan :

a. $\alpha$ : Nilai level signifikan/kesalahan tipe $1(\alpha)$ sebesar 0,05

b. $\beta$ : Power of test sebesar $80 \%(\beta=1-0,8=0,2)$ dengan standart normal deviasi $\beta=0,80$

c. $\delta$ : Difference in population mean involusi uteri pada kelompok kontrol $=6,75$

d. $\sigma:$ Standar deviasi $=5,51$

e. m : Rasio jumlah perbandingan dari kelompok kontrol dan kelompok intervensi sebesar $=1$

Proses penelitian diawali dengan pengajuan ethical clearance dan proposal penelitian ke tempat penelitian. Pada tahap pelaksanaan peneliti datang ke rumah sakit untuk melihat data ibu bersalin yang melahirkan pada hari tersebut dan mengecek karakteristik calon responden. Peneliti menentukan apakah calon responden memenuhi kriteria inklusi dan eksklusi.

Peneliti menemui responden untuk menjelaskan proses penelitian dan mendapatkan persetujuan ikut serta dalam penelitian dengan menandatangani lembar persetujuan. Kelompok intervensi pada 24 jam pertama postpartum akan diajarkan senam nifas dan pijat oksitosin oleh bidan di PMB Misni Herawati. berdasarkan booklet senam nifas yang akan diberikan kepada responden. Pada saat praktik senam nifas dan pijat oksitosin salah satu anggota keluarga hadir menyaksikan dan sama sama mempelajari gerakan senam nifas dan pijat oksitosin. Bidan mendemonstrasikan gerakan senam nifas dan pijat 
oksitosin diikuti oleh ibu dan memberikan reinforcement positif jika ibu berhasil mendemonstrasikan kembali.

Responden diminta meninggalkan nomor kontak yang bisa dihubungi untuk diingatkan dengan sms agar rutin melakukan senam nifas dan pijat oksitosin sesuai booklet dan senam nifas dilakukan 3 kali dalam seminggu selama 2 minggu dengan frekuensi waktu 2030 menit/ hari. Responden diminta memberikan alamat rumah. Pertemuan berikutnya pada hari ke 3 postpartum, saat ibu postpartum kembali ke rumah sakit untuk kontrol ulang memeriksakan kondisinya. Apabila tidak kembali maka peneliti yang datang ke rumah responden untuk mengevaluasi apakah ibu rutin melakukan senam nifas dan pijat oksitosin serta mengukur tinggi fundus uteri, untuk kunjungan rumah peneliti dibantu oleh dua asisten peneliti yang berkualifikasi pendidikan DIII Kebidanan, sebelum melakukan kunjungan rumah peneliti melakukan apersepsi dengan asisten peneliti tentang hal apa saja yang harus dievaluasi selama melakukan kunjungan rumah.

Kontrak berikutnya untuk pertemuan hari keenam, kesembilan dan keduabelas dimana peneliti datang ke rumah responden untuk mengevaluasi apakah responden rutin melakukan senam nifas dan pijat oksitosin. Kemudian peneliti mengukur tinggi fundus uteri responden. Kunjungan dilakukan sesuai kesepakatan dengan ibu. Waktu kunjungan sekitar 3060 menit.

\section{HASIL DAN PEMBAHASAN}

Penelitian telah dilakukan terhadap 60 responden yang memenuhi kriteria inklusi dan ekslusi yang terdiri dari dua kelompok (kelompok intervensi sebanyak 30 responden dan kelompok kontrol sebanyak 30 responden). Kelompok intervensi merupakan kelompok yang diberikan perlakuan dengan melaksanakan senam nifas dan pijat oksitosin. kelompok kontrol merupakan responden yang tidak diberikan perlakuan senam nifas dan pijat oksitosin.

1. Gambaran Karakteristik Responden melalui Analisis Univariat pada kelompok intervensi dan kontrol

TABEL 1.

Distribusi Frekuensi Karakteristik Responden

\begin{tabular}{|c|c|c|}
\hline Variabel & $\mathbf{N}$ & $\%$ \\
\hline $\begin{array}{l}\text { Senam Nifas dan Pijat Oksitosin } \\
\text { Diberikan senam nifas dan Pijat Oksitosin } \\
\text { Tidak diberikan senam nifas dan Pijat } \\
\text { Oksitosin }\end{array}$ & $\begin{array}{l}30 \\
30\end{array}$ & $\begin{array}{l}50,0 \\
50,0\end{array}$ \\
\hline $\begin{array}{l}\text { Usia } \\
25 \text { tahun } \\
26 \text { tahun } \\
27 \text { tahun } \\
28 \text { tahun } \\
29 \text { tahuu } \\
30 \text { tahuu } \\
31 \text { tahun } \\
32 \text { tahun } \\
33 \text { tahun }\end{array}$ & $\begin{array}{c}3 \\
7 \\
7 \\
18 \\
9 \\
10 \\
3 \\
2 \\
1\end{array}$ & $\begin{array}{l}5,0 \\
11,7 \\
11,7 \\
30,0 \\
15,0 \\
16,7 \\
5,0 \\
3,3 \\
1,7\end{array}$ \\
\hline $\begin{array}{l}\text { Paritas } \\
1 \\
2 \\
3\end{array}$ & $\begin{array}{l}35 \\
22 \\
30\end{array}$ & $\begin{array}{l}58,3 \\
36,7 \\
5,0\end{array}$ \\
\hline
\end{tabular}

Karakteristik responden dalam penelitian ini paling banyak yaitu berumur 28 tahun sejumlah 18 orang (30\%). Mayoritas paritas yang memiliki 1 anak 35 sejumlah $30(58,3 \%)$.

\section{TABEL 2.}

Uji Normalitas Data Tinggi Fundus Uteri sebelum dan sesudah perlakuan (Shapiro Wilk)

\begin{tabular}{ccc}
\hline & \multicolumn{2}{c}{$p$ value } \\
TFU & Perlakuan & Kontrol \\
\hline Sebelum & 0,001 & 0,001 \\
Sesudah & 0,009 & 0,015 \\
\hline
\end{tabular}

Tabel 2 menampilkan hasil distribusi data tinggi fundus uteri sebelum perlakuan dan sesudah perlakuan pada kelompok perlakuan dan kontrol menyatakan tidak berdistribusi normal dengan $p$ value < 0,05, hal ini menunjukkan untuk membandingkan selisih penurunan tinggi fundus uteri pada kelompok perlakuan dan kelompok kontrol adalah dengan uji statistic non parametrik mann-whitney.

TABEL 3.

Uji Homogenitas

\begin{tabular}{|c|c|c|c|}
\hline \multirow{3}{*}{ Karakteristik } & \multicolumn{2}{|c|}{ Kelompok penelitian } & \multirow{3}{*}{ Nilai $p^{*}$} \\
\hline & \multicolumn{2}{|c|}{ Perlakuan Kontrol } & \\
\hline & $\begin{array}{c}(\mathrm{n}=\mathbf{3 0}) \\
\text { Mean } \pm \text { SD }\end{array}$ & $\begin{array}{c}(\mathrm{n}=\mathbf{3 0}) \\
\text { Mean } \pm \text { SD }\end{array}$ & \\
\hline $\begin{array}{l}\text { Usia (th) } \\
25-33 \text { tahun }\end{array}$ & $28,43 \pm 2,012$ & $28,27 \pm 1,552$ & 0,721 \\
\hline $\begin{array}{l}\text { Paritas } \\
1-3\end{array}$ & $1,50 \pm 0,682$ & $1,43 \pm 0,596$ & 0,668 \\
\hline $\begin{array}{l}\text { Tinggi Fundus Uteri }(\mathrm{cm}) \\
\text { Total Pre TFU } \\
\text { Total Post TFU }\end{array}$ & $\begin{array}{c}11,68 \pm 0,609 \\
5,53 \pm 0,776\end{array}$ & $\begin{array}{c}11,90 \pm 0,724 \\
6,17 \pm 1,05\end{array}$ & $\begin{array}{l}0,215 \\
0,110\end{array}$ \\
\hline
\end{tabular}

Seterangan uji: ")Berdasarkan Uji $T$ Independent" ) Chi-Square

Tabel 3 menunjukkan tidak terdapat perbedaan yang bermakna pada karakteristik ibu antara kelompok perlakuan dan kelompok kontrol pada karakteristik usia ibu, paritas dan tinggi fundus uteri $(\mathrm{p}>0,05)$.

2. Hasil Analisis Bivariat

TABEL 4.

Perbedaan rata rata penurunan tinggi fundus uteri (involusi uteri) pada Hari 1, Hari ke 3, Hari ke 6 dan Hari ke 9 Postpartum antara kelompok perlakuan dan kelompok kontrol (Uji MannWhitney)

\begin{tabular}{ccccc}
\hline Variabel & $\begin{array}{c}\text { Intervensi } \\
(\mathrm{n}=30) \\
\text { Mean=SD }\end{array}$ & $\begin{array}{c}\text { Kontrol } \\
(\mathrm{n}=30) \\
\text { MeantSD }\end{array}$ & $\begin{array}{c}\text { Selisih } \\
\text { penurunan TFU }\end{array}$ & prailie \\
\hline IFU1 & $11,68 \pm 0,61$ & $11,90 \pm 0,72$ & 0,22 & 0,299 \\
TFU3 & $9,1 \pm 0,95$ & $11,2 \pm 0,76$ & 2,10 & 0,001 \\
IFU6 & $7,85 \pm 0,95$ & $9,27 \pm 0,86$ & 1,42 & 0,001 \\
TFU9 & $5,53 \pm 0,37$ & $6,17 \pm 1,05$ & 0,64 & 0,010 \\
\hline
\end{tabular}

Sumber Data - Uji Mann-Whitney

Tabel 4 menunjukan penurunan rerata tinggi fundus uteri pada hari ke-1 pada kelompok intervensi 
adalah 11,68 cm dengan standar deviasi $0,61 \mathrm{~cm}$, sedangkan rerata tinggi fundus uteri hari 1 pada kelompok kontrol adalah 11,90 $\mathrm{cm}$ dengan standar deviasi $0,22 \mathrm{~cm}$. Pengukuran tinggi fundus uteri hari 1 antara kelompok intervensi dan kelompok kontrol terdapat perbedaan $0,22 \mathrm{~cm}$. Hasil uji statistik didapatkan nilai $p=0,299$ berarti pada alpha $5 \%$ terlihat tidak ada perbedaan yang signifikan rerata tinggi fundus uteri antara kelompok intervensi dan kelompok kontrol.

Rerata tinggi fundus uteri pada hari ke-3 pada kelompok intervensi adalah 9,1 cm dengan standar deviasi $0,95 \mathrm{~cm}$, sedangkan rerata tinggi fundus uteri hari ke-3 pada kelompok kontrol adalah 11,2 $\mathrm{cm}$ dengan standar deviasi $0,76 \mathrm{~cm}$. Pengukuran tinggi fundus uteri hari ke-3 antara kelompok intervensi dan kelompok kontrol terdapat perbedaan $2,10 \mathrm{~cm}$. Hasil uji statistik didapatkan nilai $p=0,001$ berarti pada alpha $5 \%$ terlihat ada perbedaan yang signifikan rerata tinggi fundus uteri antara kelompok intervensi dan kelompok kontrol.

Rerata tinggi fundus uteri pada hari ke-6 pada kelompok intervensi adalah $7,85 \mathrm{~cm}$ dengan standar deviasi $0,95 \mathrm{~cm}$, sedangkan rerata tinggi fundus uteri hari ke-6 pada kelompok kontrol adalah 9,27 cm dengan standar deviasi $0,86 \mathrm{~cm}$. Pengukuran tinggi fundus uteri hari ke-6 antara kelompok intervensi dan kelompok kontrol terdapat perbedaan 1,42 cm. Hasil uji statistik didapatkan nilai $p=0,001$ berarti pada alpha $5 \%$ terlihat ada perbedaan yang signifikan rata-rata tinggi fundus uteri antara kelompok intervensi dan kelompok kontrol.

Rerata tinggi fundus uteri pada hari ke-9 pada kelompok intervensi adalah $5,53 \mathrm{~cm}$ dengan standar deviasi $0,77 \mathrm{~cm}$, sedangkan rerata tinggi fundus uteri hari ke-9 pada kelompok kontrol adalah 6,17 cm dengan standar deviasi $1,05 \mathrm{~cm}$. Pengukuran tinggi fundus uteri hari ke-9 antara kelompok intervensi dan kelompok kontrol terdapat perbedaan $0,64 \mathrm{~cm}$. Hasil uji statistik didapatkan nilai $\mathrm{p}=0,010$ berarti pada alpha $5 \%$ terlihat ada perbedaan yang signifikan rata-rata tinggi fundus uteri antara kelompok intervensi dan kelompok kontrol.

Karakteristik responden dari kedua kelompok menunjukkan tidak ada perbedaan baik dari segi usia, paritas maupun tinggi fundus uteri dengan $\mathrm{p}>0,05$. Karakteristik responden baik kelompok intervensi maupun kelompok kontrol sudah homogen.

Rerata tinggi fundus uteri antara kelompok intervensi dan kelompok kontrol terjadi penurunan. Hal ini terjadi diduga terjadi proses involusi uterus yaitu adanya perubahan retrogresif pada uterus yang menyebabkan berkurangnya ukuran uterus.4.5 Segera setelah pengeluaran plasenta terjadi kontraksi uterus, sehingga ukuran masing-masing sel menurun secara bermakna yaitu 50-90 $\mu \mathrm{m}$ kali $2,5-5 \mu \mathrm{m}$ masa post partum. Segera setelah pengeluaran plasenta tinggi fundus uteri menjadi 2 jari dibawah pusat, pada hari ke5 post partum uterus kurang lebih setinggi $7 \mathrm{~cm}$ atas simpisis atau setengah simpisis pusat. Terjadinya perubahan miometrium yang bersifat proteolisis, reorganisasi dan eksofiliasi tempat perlengketan plasenta yang ditandai dengan penurunan ukuran dan berat uterus9

Pada periode post partum, penurunan kadar hormon estrogen dan progesteron menyebabkan terjadinya autolisis yaitu perusakan secara langsung jaringan hipertrofi yang berlebihan. Perubahan lain yang terjadi pada uterus adalah intensitas kontraksi uterus meningkat secara bermakna segera setelah bayi lahir, diduga terjadi sebagai respon terhadap penurunan volume intrauterin. Hormon oksitoksin yang dilepas dari kelenjer hipofisis memperkuat dan mengatur kontraksi uterus, mengompresi pembuluh darah dan membantu hemostasis. Hal inilah yang mendasari terjadinya involusi uterus pada ibu post partum, yang dapat dinilai dengan penurunan tinggi fundus uteri. Fundus turun kira-kira $1 \mathrm{~cm}$ sampai $2 \mathrm{~cm}$ setiap 24 jam10

Penambahan 1 frekuensi setiap hari pada tiap gerakan senam nifas, juga akan lebih mening-katkan terjadinya kontraksi uterus sehingga membantu proses involusi uterus. Hal ini terlihat dari rata-rata penurunan tinggi fundus uteri pada hari 1, hari 3 dan hari 6 semakin turun dan semakin menunjukkan perbedaan tinggi fundus uteri pada setiap pengukuran.

Dengan dilaksanakannya senam nifas secara teratur sesuai dengan teknik yang diajarkan membantu menguatkan kontraksi otot rahim, mengakibatkan terjadinya ischemia dengan terkompresinya pembuluh darah sehingga aliran darah ke uterus berkurang. Jaringan mengecil diikuti dengan penurunan ukuran uterus. Menurut Harrison (2000), bahwa perubahan yang luar biasa terjadi selama masa nifas, yang memungkinkan tubuh akan kembali ke keadaan tidak hamil.19 Uterus akan mengalami proses involusi yang dapat dinilai melalui tinggi fundus uteri, namun dengan diberikan intervensi berupa senam nifas kepada ibu post partum akan membantu mempercepat proses involusi uterus.

Penelitian ini menunjukkan bahwa terdapat pengaruh yang bermakna pada kelompok intervensi. Hal ini membuktikan teori bahwa pelaksanaan senam nifas dan pijat oksitosin pada ibu post partum dapat membantu mempercepat proses involusi uteri yang salah satunya dapat dinilai melalui pengukuran terhadap tinggi fundus uteri ibu post partum.5.20

Pelaksanaan latihan fisik (senam nifas) pada ibu post partum, maka sel otot akan terangsang secara kimiawi, listrik dan mekanik untuk membangkitkan potensial aksi yang dihantarkan sepanjang membran sel, dengan adanya potensial aksi maka akan terjadi mekanisme kontraktil oleh protein kontraktil aktin dan miosin, sehingga mengu-bah energi hasil hidrolisis ATP menjadi gerakan suatu komponen seluler disepanjang komponen lainnya.21.24

Peregangan mekanis akan memodifikasi permiabilitas saluran $\mathrm{Ca}+$ di membran plasma dan 
retikulum sarkoplasma, ini membuat ion kalsium masuk ke dalam sel sehingga terjadi kontraksi otot uterus11

Latihan fisik (senam nifas) akan menyebabkan terjadinya eksitasi otot, yang akan menyebabkan terjadinya peningkatan kalsium sitosol.

Dalam penelitian Larson dkk pada tahun 2002 yang melakukan survey secara acak tentang efek senam nifas bagi ibu nifas pada 1003 wanita Amerika mengaku setelah mengikuti program senam nifas dengan latihan yang teratur mengalami pengerutan pada rahim yang lebih kuat, selain itu juga mengalami penurunan pada berat badan selama enam minggu setelah melahirkan. Dan dalam studi dari 1432 ibu nifas di Swedia yang melakukan senam nifas ditemukan bahwa mayoritas $71 \%$ wanita tersebut mengalami metabolisme tubuh lancar dan pemulihan fisik yang lebih cepat14.

Menurut Mark, Rapaport, Schettler, et al., (2012) dalam The Journal Of Alternative And Complementary Medicine, bahwa dari data penelitian menunjukkan bahwa terapi pijat memiliki efek secara biologis, jika dilakukan 2 kali dalam 1 minggu dengan sentuhan ringan mempunyai efek perubahan pada neuroendokrin yang dapat memicu pelepasan oksitosin dan dapat menjaga kesetabilan oksitosin.Oksitosin juga disintesis oleh neuron parvoselular dari paraventricular nucleus dari berbagai arah pusat sistem saraf termasuk saraf tulang belakang. Pada tulang belakang terdapat saluran yang dapat mengeluarkan oxytocinergic yang bertugas mengikat hormon oksitosin, pada lapisan permukaan dorsal horn daerah otonom (intermediolateral columns, intermediomedial grey matter, lamina $\mathrm{X}$ dan sacral parasimpathetic nucleus)2.

Efek fisiologis dari pijat oksitosin ini adalah merangsang kontraksi otot polos uterus baik pada proses saat persalinan maupun setelah persalinan sehinggi dapat mempercepat proses involusi uteri.

\section{SIMPULAN DAN SARAN}

Terdapat pengaruh yang signifikan senam nifas dan pijat oksitosin terhadap involusi uteri pada ibu postpartum. Bagi peneliti berikutnya dapat melakukan follow up pelaksanaan senam nifas dan pijat oksitosin dengan melakukan kunjungan rumah seminggu 3 kali sesuai dengan jadwal ibu melakukan senam nifas sehingga dapat memonitoring dan evaluasi senam nifas dengan baik

\section{UCAPAN TERIMA KASIH}

Kemenristekdikti,L2DIKTI, Praktik Mandiri Bidan Misni Herawati, S.Tr.Keb dan PMB Husniyati, Am.Keb, Am.Keb serta STIKes Muhammadiyah Palembang yang telah memberikan biaya penelitian sehingga penelitian bisa berjalan lancar

\section{DAFTAR RUJUKAN}

[1] Saleha, S. (2009). Asuhan Kebidanan Pada Masa Nifas. Jakarta: Salemba Medika

[2] Cuningham FG, Leveno K, Bloom SL, Hauth C, Rause D, Spong CY.(2012). Obstetri Williams (terjemahan). Jakarta: EGC

[3] Breton J.D., Veinante P., Bronner S.U.(2008). Research Oxytocin Induced Antinocepcition In The Spnal Cord Is Mediated By A Subpopulation Of Glutamatergic Neurons In Lamina I-II Which Amplifi GABAergic Inhibition. BioMed Access. 1-12.

[4] Mark H., Rappaport M.D., Schettler P., PhD1., Bresee C, M.S2., (2012). A Pleminari Study Of The Effects Of Repeated Massage On Hipothalamic-Pituitari-Adrenal And Immune Funtion In Healthy Individuals: A Study Of Mechanisms of Action And Dosage, The journal of alternative and complementary medicine. 789797.Murray R, Granner DK, Roodwell V. Biokimia Harper Jakarta: EGC; 2009. hlm. 582-604.

[5] Guyton A, Hall J. (2017) Buku ajar fisiologi kedokteran. Jakarta: EGC.

[6] ACOG (2015) Screening for perinatal depression. Committee Opinion No. 630. Obstetrics Gynecology, 125: 1268-71.

[7] Lowdermilk DL, Jensen MD.(2005). Buku Ajar Keperawatan Maternitas (Maternity Nursing) Edisi 4, Maria A Wijayarti dan Peter Anugerah (penterjemah). Jakarta: EGC

[8] Dharma, K.K. (2011) Metodologi penelitian keperawatan : Panduan melaksanakan dan menerapkan hasil penelitian. Jakarta :Trans InfoMedia

[9] Khairani L, Komariah M, Mardiah W. (2012) Pengaruh Pijat Oksitosin Terhadap Involusi Uterus Pada Ibu Post Partum di Ruang Post Partum Kelas III RSHS Bandung. Tesis Fakultas Ilmu Keperawatan Universitas Padjajaran

[10] Hamranani S., (2010) Pengaruh Pijat Oksitosin Terhadap Involusi Uterus Pada Ibu Post Partum Dengan Persalinan Lama Di Rumah Sakit Wilayah Kabupaten Klaten.Tesis.Depok : Jakarta

[11] Brayshaw, E., (2008)Senam hamil dan senam nifas pedoman praktis bidan. Jakarta: EGC.

[12] Bobak, I.M., Lowdermilk, D.L., Jensen, M.D. \& Perry, S.E. (2005) Buku ajar keperawatan maternitas. Edisi 4. Alih bahasa: Maria \& Peter. Jakarta: EGC.

[13] Varney, Helen., (2002). Buku Saku Bidan. Jakarta: EGC.

[14] Larson M (2002) Effect of postpartum exercise on mothers and their offspring: a review of the literature. Obesity research. 10:841-53

\section{PROFIL PENULIS UTAMA}

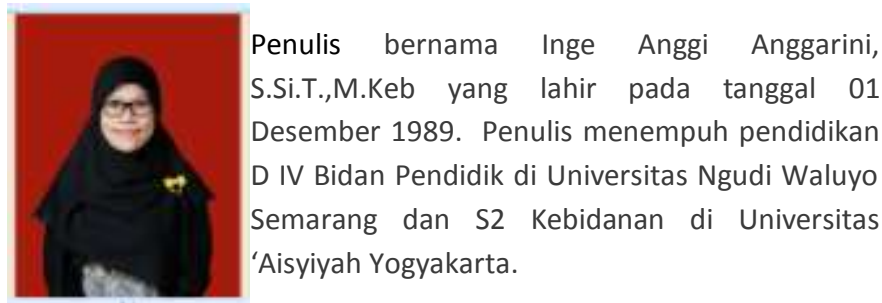

